\title{
Interkalasi Ion Mefenamat pada Host Mg/Al Hidrotalsit sebagai Rancangan Obat Lepas Lambat
}

\author{
Fajar Indah Puspita Sari \\ Jurusan Kimia, Universitas Bangka Belitung, Jl. Kampus Terpadu UBB, Kel. Balunijuk, Kec. Merawang, \\ Kabupaten Bangka, Kepulauan Bangka Belitung 33172 \\ Email: fajar-indah@ubb.ac.id
}

Received: April 2018; Revised: July 2018; Accepted: November 2018; Available Online: November 2018

\begin{abstract}
Abstrak
Tujuan dari penelitian ini adalah untuk menginterkalasikan ion mefenamat pada struktur antarlapis $\mathrm{Mg} / \mathrm{Al}$ hidrotalsit dan melakukan uji pelepasan ion mefenamat dari host antarlapis hidrotalsit untuk mengetahui potensinya sebagai rancangan obat lepas lambat. Telah dilakukan interkalasi ion mefanamat ke dalam struktur antar lapis $\mathrm{Mg} / \mathrm{Al}$ hidrotalsit melalui metode penukaran ion. Keberhasilan tersebut dikonfirmasi oleh data XRD, difraktogram sebelum dan setelah interkalasi menunjukkan pergeseran pada $\mathrm{d}_{003}, \mathrm{~d}_{006} \mathrm{dan} \mathrm{d}_{009}$. Perubahan pada $d_{003}$ dari $8.717 \AA$ menjadi $22.017 \AA$ menunjukkan bahawa ion mefenamat telah masuk pada antar lapis $\mathrm{Mg} / \mathrm{Al}$ hidrotalsit. Analisis FTIR mengkonfirmasi bahwa ion mefenamat telah berhasil menggantikan ion nitrat pada antar lapis hidrotalsit. Data FTIR menunjukkan adanya serapan simetri dan asimetri gugus karboksilat pada 1381 dan $1612 \mathrm{~cm}^{-1}$ dari ion mefenamat. Telah dipelajari juga kinetika penukaran dan pelepasan ion mefenamat dari host $\mathrm{Mg} / \mathrm{Al}$ hidrotalsit untuk menentukan potensinya sebagai desain obat lepas lambat. Hasil menunjukkan, ion mefenamat dapat dilepas dari host antarlapis hidrotalsit selama 6 jam, sehingga $\mathrm{Mg} / \mathrm{Al}$ hidrotalsit berpotensi untuk digunakan dalam rancangan obat lepas lambat.
\end{abstract}

Kata kunci: Hidrotalsit, ion mefenamat, interkalasi, penghantaran obat, lepas lambat

\begin{abstract}
The aim of this study was to intercalate mefenamic ions in the interlayer structure of $\mathrm{Mg} / \mathrm{Al}$ hydrotalcite and to test the release of mefenamic ion from host hydrotalcite interlays to determine its potential as a slow release drug design. Intercalation of mefenamic ions into interlayer structure of $\mathrm{Mg} / \mathrm{Al}$ hydrotalcite by ion exchange has been studied. This success intercalation was confirmed by XRD data, diffractogram before and after intercalation showed a shift of $d_{003}, d_{006}$ and $\mathrm{d}_{009}$. The change of $d_{003}$ from $8.717 \AA$ to $22.017 \AA$ indicates that the mefenamic ion has entered the interlayers of hydrotalcite. The FTIR analysis confirms that the nitrate ion was successfully replaced by mefenamic ions in the hydrotalcite interlayer. FTIR data indicate the absorption of symmetry and asymmetry of carboxylic groups in 1381 and $1612 \mathrm{~cm}^{-1}$ of the mefenamic ion. Have studied ion exchange kinetics and release of mefenamic ions from hydrotalcite hosts to determine their potential as a slow-release drug design. The result show mefenamic ion can be released from the hydrotalcite host for 6 hours. So that $\mathrm{Mg} / \mathrm{Al}$ hydrotalcite has the potential to be used in slow release drug design.
\end{abstract}

Keywords: Hydrotalcite, mefenamic ions, intercalations, drug delivery, slow release.

DOI: http://10.15408/jkv.v4i2.7600

\section{PENDAHULUAN}

Sistem penghantaran obat yang saat ini dikembangkan selalu mengarah pada bagaimana mendesain suatu sistem yang dapat memaksimalkan efek terapi obat, sekaligus meminimalkan efek samping yang ditimbulkannya. Dasar pemikiran dari sistem penghantaran obat sustained release adalah 
mengoptimalkan sifat biofarmasi, farmakokinetik dan farmakodinamik obat sehingga fungsinya dapat maksimal, efek samping berkurang dan penyembuhan penyakit tercapai (Pundir et al., 2017). Frekuensi pemberian obat yang semakin sering akan meningkatkan kemungkinan terjadinya efek samping yang semakin besar. Teknologi obat lepas lambat belakangan ini menjadi trend penelitian yang cukup popular. Sediaan obat lepas lambat merupakan bentuk khusus yang dirancang untuk memiliki waktu dan jumlah pelepasan terkontrol. Keunggulan yang ditawarkan dari sediaan jenis ini yaitu dapat mencapai target dan mempertahankan kadar terapi obat dalam darah pada kurun waktu yang panjang sehingga dapat mengurangi frekuensi konsumsi obat yang sekaligus berarti menurunkan potensi timbulnya efek samping (Shargel, 2005). Dengan mendesain sistem penghantaran obat menuju target dan rute yang dilewati bahan aktif obat dapat memecahkan beberapa masalah tersebut (Kumari et al., 2010).

Asam mefenamat merupakan salah satu dari golongan Obat Anti Inflamasi NonSteroids (OAINS) yang memiliki aksi kerja sebagai inhibitor siklooksigenase, analgesik dan antiinflamasi. Obat golongan ini memiliki masa kerja yang singkat sehingga diperlukan sistem penghantaran yang dapat mengontrol pelepasan obat untuk dapat memperpanjang masa kerjanya. Golongan OAINS memiliki gugus senyawa organik aromatis dengan muatan situs negatif yang dapat dipertukarkan dengan anion pada antarlapis hidrotalsit yang bermuatan positif.

Penggunaan material berlapis sebagai host atau matriks pelepasan obat telah lama dikenal. Hidrotalsit sebagai salah satu contoh material berlapis selain sebagai matriks juga memiliki keunggulan yaitu dapat meningkatkan kelarutan beberapa obat yang sukar larut seperti indometasin (Ambrogi et al., 2003). Hidrotalsit merupakan material berlapis yang memiliki sifat biokompatibel, sehingga penggunaannya dalam bidang farmasi cukup luas. Diantara aplikasi hidrotalsit dalam bidang farmasi yang telah diteliti misalnya: sebagai tabir surya, antasida, host untuk menginterkalasikan berbagai jenis obat seperti penurun kadar kolesterol, antiinflamasi, antikanker, antibiotik, dan antikoagulan dengan waktu paruh singkat (Panda et al., 2009; Choy et al., 1999; Carja et al., 2009 dalam Del Arco et al., 2010). Del Arco et al., (2007) telah melakukan interkalasi asam mefenamat dan meklofenamat pada struktur antarlapis hidrotalsit $\mathrm{Mg} / \mathrm{Al}$ dengan anion antarlapis $\mathrm{Cl}$ menggunakan metode kopresipitasi dan rekonstruksi struktur, namun belum melakukan uji pelepasan anion obat tersebut dari matriks hidrotalsit.

Beberapa keunggulan material berlapis tersebut dalam penerapan controlled release drugs menyebabkan ketertarikan untuk dapat dikembangkan lebih lanjut. Tujuan dari penelitian ini adalah untuk mempelajari interkalasi ion mefenamat pada struktur antarlapis hidrotalsit, pelepasan ion mefenamat dari host $\mathrm{Mg} / \mathrm{Al}$ Hidrotalsit, dan kinetika pelepasan ion mefenamatdari host $\mathrm{Mg} / \mathrm{Al}$ Hidrotalsit guna mengetahui potensi $\mathrm{Mg} / \mathrm{Al}$ hidrotalsit sebagai host rancangan obat lepas lambat.

\section{METODE PENELITIAN Bahan dan alat}

$\mathrm{Mg} / \mathrm{Al}$ Hidrotalsit $\mathrm{NO}_{3}^{-}$hasil sintesis dengan perbandingan $\mathrm{Mg}: \mathrm{Al}=2: 1$ (Sari, 2017), $\mathrm{KOH}$ (Merck), trishidroksimetilaminometan (Merck), $\quad \mathrm{H}_{3} \mathrm{PO}_{4}$ (Merck), asam mefenamat (PT. Indofarma, Bekasi), gas Nitrogen (PT. Samator, Kendal).

Instrumen yang digunakan dalam analisis penelitian ini adalah difraktometer sinar-X (XRD, Shimadzu S-6000), spektrofotometer inframerah (FTIR, Shimadzu Prestige-21), dan spektrofotometer UV- Vis (Hitachi, Model 150- 20).

\section{Prosedur Penelitian}

\section{Interkalasi asam mefenamat dalam antar lapisan hidrotalsit}

Metode interkalasi anion mefenamat yang digunakan mengacu pada Del Arco et al. (2009) dengan modifikasi pada pembuatan larutan natrium mefenamat yang mengacu pada Bani-Jaber et al., (2007). Larutan garam natrium mefenamat ditambahkan ke dalam larutan yang mengandung 2.36 gram hidrotalsit dalam $50 \mathrm{~mL}$ akuabides. Larutan diaduk hingga homogen dan ditambahkan larutan $\mathrm{KOH} 2 \mathrm{M}$ hingga $\mathrm{pH} \sim 8$. Suspensi yang terbentuk terus diaduk selama 4 jam. Endapan yang diperoleh disentrifugasi, kemudian dicuci. Endapan dikeringkan dalam oven pada suhu $70^{\circ} \mathrm{C}$ selama 20 jam. Endapan kering dihaluskan dan dikarakterisasi menggunakan FTIR dan XRD. 


\section{Studi Pelepasan Asam Mefenamat}

Metode yang digunakan mengacu pada

United State Pharmacopeia (U.S. Pharmacopeia, 2007) dan British Pharmacopoea 2009 dengan beberapa penyesuaian. Sampel obat mefenamat sebanyak $25 \mathrm{mg}$ dilarutkan dalam medium buffer tris $\mathrm{pH} 9$ kemudian dimasukkan ke dalam shaker incubator yang memiliki suhu $37 \pm 0.2{ }^{\circ} \mathrm{C}$. Medium pelarutan yang digunakan adalah $90 \mathrm{~mL}$ tris buffer (trishidroksimetilaminometan $+\mathrm{H}_{3} \mathrm{PO}_{4}, \mathrm{pH}=9$ ) $0.05 \mathrm{M}$. Volume sampel yang telah diambil diganti dengan buffer tris sehingga volume selalu tetap. Sampel obat yang lepas ke dalam medium diambil pada menit ke 30,60, 90, 120, 180, 240, 300, dan 360. Sampel yang diambil kemudian dianalisis dengan menggunakan spektrofotometer UV-Vis pada panjang gelombang maksimum $283 \mathrm{~nm}$.

\section{HASIL DAN PEMBAHASAN Interkalasi ion mefenamat pada antar lapis hidrotalsit}

Hidrotalsit yang digunakan dalam penelitian ini adalah hasil sintesis dengan metode kopresipitasi hidrothermal dan diperoleh rumus molekul $\mathrm{Mg}_{0,686} \mathrm{Al}_{0,313}(\mathrm{OH})_{2}\left(\mathrm{NO}_{3}\right)_{0,31} \cdot 0.848 \mathrm{H}_{2} \mathrm{O}$ (Sari, 2017). Struktur dua dimensi hidrotalsit memiliki fleksibelitas yang tinggi untuk dapat diisi oleh molekul dengan berbagai ukuran.
Interkalasi ion mefenamat dilakukan dengan metode penukaran ion. Ion mefenamat menggantikan ion nitrat awal yang berada pada antar lapis hidrotalsit. Tujuan dari proses interkalasi adalah mengusir anion awal yaitu nitrat dan mengganti dengan anion baru, yang secara otomatis akan memperbesar jarak antar lapisan hidrotalsit.

Untuk mengkonfirmasi terjadinya penukaran ion pada antarlapis hidrotalsit dilakukan karekterisasi XRD. Difraktogram hidrotalsit sebelum dan setelah interkalasi disajikan pada Gambar 1. Anion mefenamat memiliki ukuran yang jauh lebih besar dari anoin nitrat. Hal ini yang menyebabkan terjadinya pergeseran puncak $d_{003}$ hidrotalsit dan magnetit-hidrotalsit setelah proses interkalasi. Pertukaran anion yang berdimensi kecil oleh anion yang berdimensi lebih besar menyebabkan kenaikan jarak antar bidang kristal. Terjadi pergeseran puncak $d_{003}, d_{006}$ dan $d_{009}$ antara sebelum dan setelah interkalasi. Nilai $d_{003}$ untuk hidrotalsit awal sebesar 8.717 A setelah proses interkalasi menjadi $22.017 \AA$. Nilai ini sesuai dengan pernyataan Del Arco et al. (2009) bahwa nilai $d_{003} \mathrm{Mg} / \mathrm{Al} \mathrm{Cl}$ hidrotalsit setelah terinterkalasi mefenamat berubah menjadi $22.5 \AA$ A. Nilai yang hampir berdekatan ini menunjukkan bahwa anion mefenamat telah berhasil masuk kedalam ruang antar lapisan hidrotalsit.

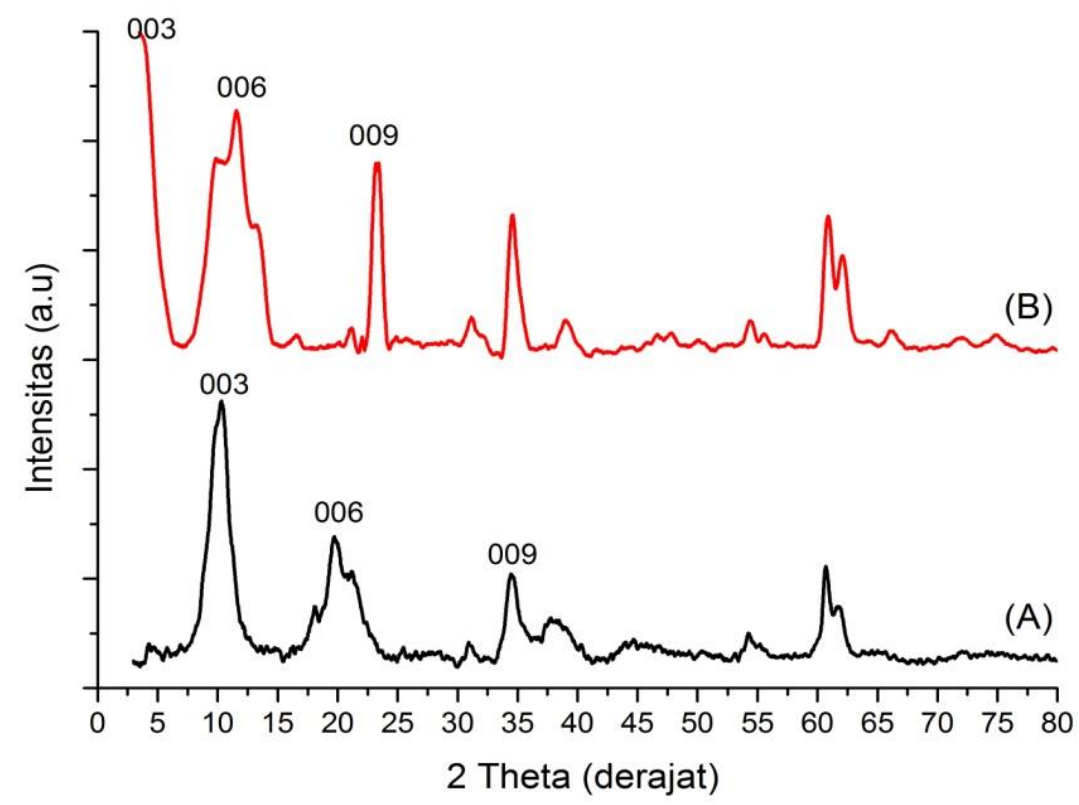

Gambar 1. Difraktogram (A) hidrotalsit dan (B) hidrotalsit terinterkalasi mefenamat 


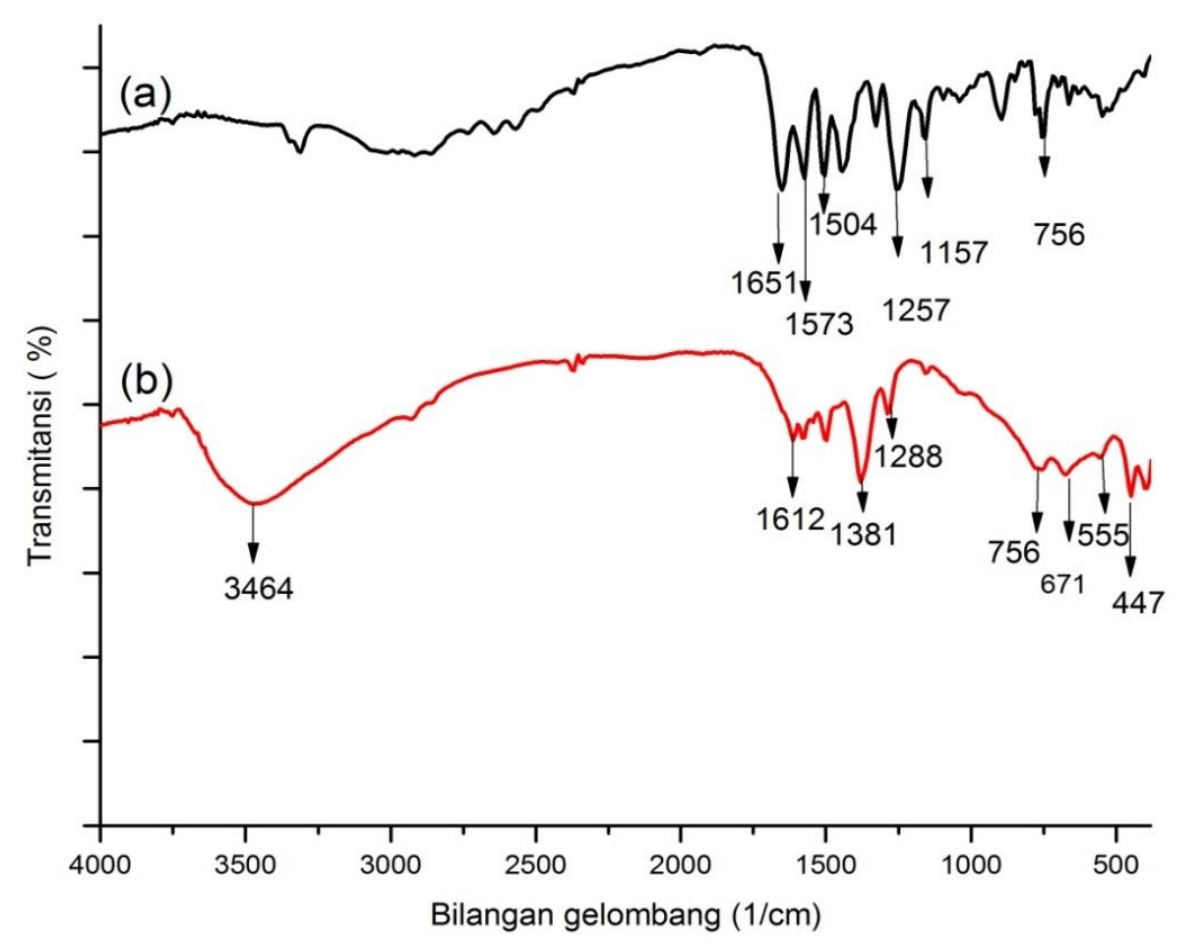

Gambar 2. Spektra FTIR (a) Mefenamat (b) Mg/Al hidrotalsit terinterkalasi mefenamat

Gambar 2 menyajikan spektra FTIR asam mefenamat, dan mefenamat terinterkalasi pada antar lapis hidrotalsit. Bilangan gelombang yang karakteristik untuk asam mefenamat yaitu pada: 1255, 1647, 1572, 1504, 757, dan $1163 \mathrm{~cm}^{-1}$ (Osselton et al ., 2003). Pada penelitian ini spektra asam mefenamat menunjukkan adanya 4 serapan tajam pada daerah $1600-1400 \mathrm{~cm}^{-1}$, yang merupakan serapan dari C-C aromatik, $756 \mathrm{~cm}^{-}$ ${ }^{1}$ (aromatik dengan subtituen orto) dan 1257 $\mathrm{cm}^{-1}$ (C-O). Hal serupa diungkapkan oleh Del Arco et al. (2004) yang menyebutkan bahwa vibrasi C-C aromatik ditunjukkan pada 1613, 1579, 1484, dan $1467 \mathrm{~cm}^{-1}$. Adanya asam bebas mefenamat ditunjukkan dengan bilangan gelombang $1651 \mathrm{~cm}^{-1}$ sesuai dengan referensi $\left(1649 \mathrm{~cm}^{-1}\right)$ (Del Arco et al., 2009).

Spektra FTIR asam mefenamat terinterkalasi pada antar lapis hidrotalsit menunjukkan adanya serapan pada bilangan gelombang 555 dan $447 \mathrm{~cm}^{-1}$ yang merupakan vibrasi metal-oksida, mengindikasikan bahwa ikatan logam dalam struktur hidrotalsit tidak berubah. Serapan dari gugus-gugus karakteristik mefenamat yang melemah dan sedikit bergeser diperkirakan karena interaksi elektrostatik dengan lapisan hidrotalsit (Del Arco et al., 2009). Serapan asam bebas dari mefenamat tidak lagi muncul setelah proses interkalasi, dan digantikan oleh serapan asimetri dan simetri gugus karboksilat yang muncul pada 1612 dan $1381 \mathrm{~cm}^{-1}$. Wang et al. (2010) menyatakan vibrasi asimetri dan simetri $\left(\mathrm{COO}^{-}\right)$pada bilangan gelombang $1597 \mathrm{~cm}^{-1}$ dan $1391 \mathrm{~cm}^{-1}$. Munculnya serapan karboksilat dan hilangnya serapan asam bebas dari mefenamat setelah interkalasi mengkonfirmasi bahwa anion mefenamat telah masuk ke dalam antar lapisan hidrotalsit.

Data XRD dan FTIR di atas, menunjukkan bahwa penukaran ion tidak berlangsung secara sempurna, jumlah ion mefenamat yang menggantikan ion nitrat dapat dihitung dengan menentukan jumlah ion mefenamat yang masuk dalam antar lapisan hidrotalsit kemudian dibandingkan dengan jumlah anion nitrat awal. Penentuan jumlah anion yang berhasil ditukar dilakukan menggunakan metode spektrofotometri pada panjang gelombang maksimum mefenamat $283 \mathrm{~nm}$. Dari perhitungan diperoleh jumlah anion tertukar pada $\mathrm{Mg} / \mathrm{Al} \mathrm{NO}_{3}$ hidrotalsit sebesar 0.258 mmol mefenamat dari 0.334 mmol nitrat atau sebesar $77.33 \%$.

Kinetika penukaran ion nitrat terhadap mefenamat dipelajari dengan variabel waktu kontak. Penukaran diamati dari 30 menit 
hingga diperoleh kesetimbangan, dimana tidak terjadi penambahan jumlah anion tertukar sering dengan pertambahan waktu. dan diperoleh hasil sebagai berikut:

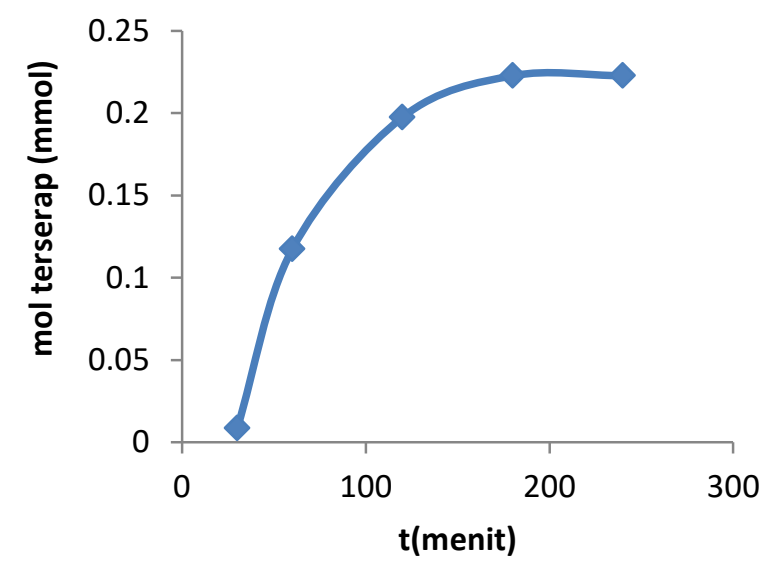

Gambar 3. Plot pengaruh waktu kontak terhadap jumlah mol mefenamat terserap.

Dari grafik tersebut terlihat bahwa semakin lama waktu kontak, jumlah mol mefenamat terserap semakin besar sampai tercapai kesetimbangan. Waktu dimana terjadi kesetimbangan ini merupakan waktu optimum penukaran ion. Waktu kesetimbangan untuk penukaran anion mefenamat terhadap anion nitrat pada hidrotalsit maupun magnetithidrotalsit dicapai pada saat 180 menit.

Untuk mempelajari lebih lanjut mengenai mekanisme penukaran ion, maka data pengaruh waktu terhadap jumlah ion tertserap diplotkan beberapa model kinetika, yaitu kinetika orde satu dan kinetika orde dua. Persamaan kinetika orde 1 yaitu $\operatorname{lnC}_{a}=-k_{1} t+$ lnCo (Moore, 1995). Parameter konstanta laju reaksi $\left(\mathrm{k}_{1}\right)$ pada penelitian ini diperoleh melalui plot hasil pengukuran $\ln (\mathrm{Co}-\mathrm{Ca})$ yang merupakan konsentrasi mefenamat tersisa dalam larutan versus waktu pengambilan sampel. Kinetika reaksi orde 2 menggunakan persamaan $(1 / \mathrm{Ca})=\mathrm{k}_{2} \mathrm{t}+(1 / \mathrm{Co})$. Hasil plot dua model kinetika reaksi tersebut diperoleh nilai parameter kinetika sebagai berikut:

Tabel 1. Parameter kinetika penukaran ion

\begin{tabular}{cccc}
\hline \multirow{2}{*}{ Sampel } & Model & \multicolumn{2}{c}{ Nilai parameter } \\
\cline { 3 - 4 } & kinetika & $\mathbf{k}$ & $\mathbf{R}^{\mathbf{2}}$ \\
\hline \multirow{2}{*}{ Hidrotalsit } & Orde-1 & 0.0081 & 0.946 \\
& Orde-2 & $9 \times 10^{-6}$ & 0.992 \\
\hline
\end{tabular}

Berdasarkan nilai koefisien korelasi $\left(\mathrm{R}^{2}\right)$ yang diperoleh maka model kinetika penukaran ion mefenamat terhadap anion nitrat pada hidrotalsit yang diusulkan adalah kinetika orde dua dengan tetapan laju reaksi untuk hidrotalsit $9 \times 10^{-6} \mathrm{ppm}^{-1}$. menit ${ }^{-1}$.

\section{Studi pelepasan ion mefenamat dari host hidroralsit}

Studi pelepasan mefenamat dari hidrotalsit dipelajari dengan mengamati pengaruh waktu terhadap jumlah mefenamat terlepas dalam medium pelepasan. Studi pelepasan mefenamat dilakukan pada kondisi yang mendekati sistem tubuh, yaitu mengacu pada prosedur standar USP pada suhu $37{ }^{\circ} \mathrm{C}$ dan medium buffer tris $\mathrm{pH} 9$ dengan beberapa modifikasi. Sampel mefenamat terlindung dalam struktur antarlapis hidrotalsit dimasukkan ke dalam medium pelepasan, kemudian jumlah mefenamat terlepas diukur dengan mengambil sampel pada menit ke 30, 60, 90, 120, 180, 240, 300, dan 360. Plot kurva pengaruh waktu terhadap pelepasan ion mefenamat dari hidrotalsit disajikan pada gambar berikut:

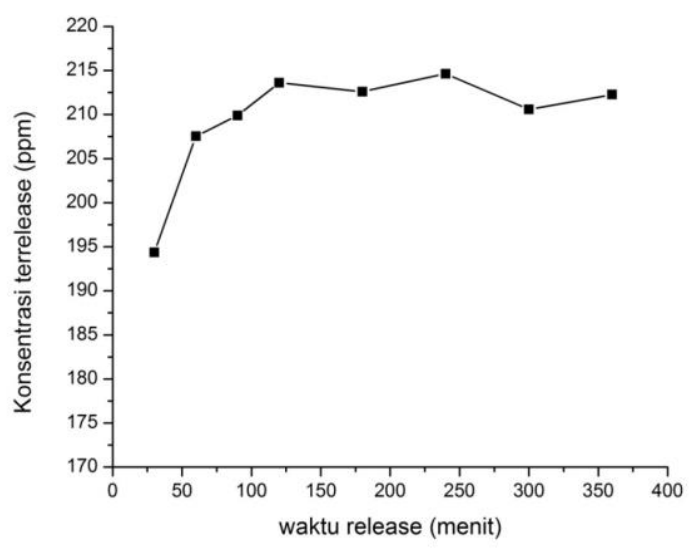

Gambar 4. Plot waktu release lawan konsentrasi ion mefenamat dari hidrotalsit.

Dari plot diatas terlihat bahwa konsentrasi mefenamat terlepas dalam medium pelepasan meningkat seiring penambahan waktu, pada saat 120 menit konsentrasi mefenamat yang terlepas mencapai maksimum kemudian mengalami penurunan. Titik ini disebut titik optimum pelepasan ion mefenamat dari host hidrotalsit. Menurut Betageri et al., (1995) mefenamat tanpa terlindung dalam matriks terlepas mendekati sempurna pada 2 jam. Dengan kata lain, 
interkalasi ion mefenamat di dalam antar lapisan hidrotalsit berhasil memperpanjang waktu pelepasannya.

\section{SIMPULAN}

$\mathrm{Mg} / \mathrm{Al}$ Hidrotalsit dengan anion antarlapis $\mathrm{NO}_{3}^{-}$dapat digunakan sebagai penukar ion dalam memodifikasi sistem penghantaran obat lepas lambat asam mefenamat. Penukaran ion cukup efektif dalam rancangan obat lepas lambat sistem host-guest. Hasil menunjukkan ion mefenamat dapat dilepas hingga 6 jam dari antar lapis hidrotalsit.

\section{UCAPAN TERIMAKASIH}

Terimkasih kepada Bapak Dr. Roto, M.Eng dan Bapak Dr. Rer.nat. Nurul Hidayat Aprilita, Departemen Kimia FMIPA UGM atas bimbingannya.

\section{DAFTAR PUSTAKA}

Ambrogi V, Fardella G, Grandolini G, Nocchetti M, Perioli L. 2003. Effect of hydrotalcitelike compounds on the aqueous solubility of some poorly water-soluble drugs. Journal of pharmaceutical sciences. 92(7): 1407-1418.

Bani-Jaber A, Hamdan I, Al-Khalid B. 2007. Sodium mefenamate as a solution for the formulation and dissolution problems of mefenamic acid. Chem. Pharm. Bull. 55(8): 1136-1140.

Betageri GV, Jenkins SA, Parsons D. 1993 Liposome Drug Delivery Systems. Technomic publishing co. Inc.

British Pharmacopeia. 2009. The Stationary Office under license from the Controller of Her Majesty's Stationary Office for the Department of Health on Behalf of the Health Medicines, London, Volume I and II, 3023-3025, 10952.

Carja G, Kameshima Y, Ciobanu G, Chiriac H, Okada K. 2009. New hybrid nanostructures based on oxacillinhydrotalcite-like anionic clays and their textural properties. Micron. 40(1): 147150.

Choy JH, Kwak SY, Park JS, Jeong YJ, Portier J. 1999. Intercalative nanohybrids of nucleoside monophosphates and DNA in layered metal hydroxide. Journal of the
American Chemical Society. 121(6): 13991400 .

Del Arco M, Fernández A, Martín C, Rives V. 2009. Release studies of different NSAIDs encapsulated in $\mathrm{Mg}, \mathrm{Al}, \mathrm{Fe}$ hydrotalcites. Applied Clay Science. 42(34): $538-544$.

Del Arco M, Fernandez A, Martin C, Rives V. 2010. Solubility and release of fenbufen intercalated in $\mathrm{Mg}, \mathrm{Al}$ and $\mathrm{Mg}, \mathrm{Al}, \mathrm{Fe}$ layered double hydroxides(LDH): The effect of Eudragits S 100 covering. J. Solid State Chem. 183: 3002-3009.

Del Arco M, Gutiérrez S, Martín C, Rives V, Rocha J. 2004. Synthesis and characterization of layered double hydroxides (LDH) intercalated with nonsteroidal antiinflammatory drugs (NSAID'S). J. Solid State Chem. 177: 3954-3962.

Del Arco M, Fernández A, Martín C, Rives V. 2007. Intercalation of mefenamic and meclofenamic acid anions in hydrotalcitelike matrices. Appl. Clay Sci. 36: 133-140.

Kumari A, Yadav SK, Yadav SC. 2010. Biodegradable polymeric nanoparticles based drug delivery systems. Colloids and Surfaces B: Biointerfaces. 75(1): 1-18.

Moore WJ. 1995. Physical Chemistry, $2^{\text {nd }}$ ed, Prentice-Hall Inc., Great Britain.

Osselton D, Widdop B, Galichet LY. 2003. Clarke's analysis of Drugs and Poisons. London (UK): Pharmaceutical Press.

Panda HS, Srivastava R, Bahadur D. 2009. In-vitro release kinetics and stability of anticardiovascular drugs-intercalated layered double hydroxide nanohybrids. The Journal of Physical Chemistry B. 113(45): 15090-15100.

Pundir S, Badola A, Sharma D. 2017. Sustained release matrix technology and recent advance in matrix drug delivery system: a review. International Journal of Drug Research And Technology. 3(1): 8.

Sari FIP. 2017. Sintesis, karakterisasi nanopartikel magnetit, $\mathrm{Mg} / \mathrm{AlNO}_{3}$-hidrotalsit dan komposit magnetit-hidrotalsit. Jurnal Kimia VALENSI. 3(1): 44-49. 
Shargel, Leon, BC. Andrew. 2005. Biofarmasetika dan Farmakokinetika Terapan. Surabaya (ID): Airlangga Univeersity Press.

U.S. Pharmacopeia. The United States Pharmacopeia, USP 30/The National Formulary, NF 25. 2007 Rockville, MD: U.S. Pharmacopeial Convention, Inc., p.2635.
Wang J, Zhou J, Li Z, Liu Qi, Yang P. 2010. Design of Magnetic and Fluorecent Mg-Al Layered Double Hydroxide by intoducing $\mathrm{Fe}_{3} \mathrm{O}_{4}$ Magnetic Nanoparticles and Eu3+ Ions for Intercalation of Glycine. Mater. Res. Bull. 45: 640-645. 